\title{
COMPARISON OF LIGHT'S CRITERIA AND PLEURAL FLUID CHOLESTEROL TO DISTINGUISH EXUDATIVE AND TRANSUDATIVE PLEURAL FLUID
}

\author{
Kali Gandhi', Uday Raj Singh ${ }^{2}$, P. C. Kol ${ }^{3}$, Ashutosh Garg ${ }^{4}$, Krati Gandhi' ${ }^{5}$, S. K. Sutrakar ${ }^{6}$, Hemlata Bamoriya ${ }^{7}$ \\ 1 Junior Resident, Department of Pathology, S. S. Medical College, Rewa, Madhya Pradesh. \\ 2 Professor and HOD, Department of Pathology, S. S. Medical College, Rewa, Madhya Pradesh. \\ ${ }^{3}$ Associate Professor, Department of Pathology, S. S. Medical College, Rewa, Madhya Pradesh. \\ ${ }^{4}$ Demonstrator, Department of Microbiology, S. S. Medical College, Rewa, Madhya Pradesh. \\ 5Junior Resident, Department of OBG, Pt. B. D. Sharma PGIMS, Rohtak, Haryana. \\ ${ }^{6}$ Associate Professor, Department of Pathology, S. S. Medical College, Rewa, Madhya Pradesh. \\ 7Junior Resident, Department of Pathology, S. S. Medical College, Rewa, Madhya Pradesh.
}

ABSTRACT
BACKGROUND
Light's criteria is the gold standard to differentiate transudative pleural effusion from exudative pleural effusion, but it requires
four biochemical estimations which in developing countries such as India, may not be feasible in every patient due to economic
constraints.

\section{MATERIALS AND METHODS}

In this prospective study, 60 patients with pleural effusion were included. Pleural fluid total protein, LDH and cholesterol as well as serum total protein and LDH levels along with other investigations were studied. Clinical classification of transudate or exudate was done based on aetiology.

\section{RESULTS}

Based on clinical signs and symptoms, chest radiograph and other investigations, 52 of these effusions were classified as exudates and 8 as transudates. Using the pleural fluid cholesterol cut-off point $>45 \mathrm{mg} / \mathrm{dL}$ to differentiate exudates and transudates, the sensitivity, specificity, positive predictive value (PPV) and the negative predictive value (NPV) were found to be $100 \%$. Using Light's criteria to differentiate exudates and transudates, the sensitivity, specificity, positive predictive value (PPV) and negative predictive value (NPV) were found to be $98 \%, 87.5 \%, 98 \%$ and $87.5 \%$ respectively. The differences resulted from misclassification of 1 expected exudate as transudate out of 52 and 1 expected transudate as exudate out of 8 by Light's criteria.

\section{CONCLUSION}

Pleural fluid cholesterol is a simple, cost effective and useful parameter in differentiating pleural exudates from transudates, with the advantage of requiring only one laboratory determination and no simultaneous blood sample, as compared to the use of Light's criteria.

\section{KEYWORDS}

Light's Criteria, Pleural Fluid Cholesterol, Exudates and Transudates.

HOW TO CITE THIS ARTICLE: Gandhi K, Singh UR, Kol PC, et al. Comparison of Light's criteria and pleural fluid cholesterol to distinguish exudative and transudative pleural fluid. J. Evolution Med. Dent. Sci. 2017;6(38):3056-3060, DOI: $10.14260 /$ Jemds/2017/659

\section{BACKGROUND}

Pleural effusion is a manifestation of several diseases, both pulmonary and extrapulmonary. ${ }^{1}$ Based on underlying pathological abnormality and mechanism of formation, effusion can be either "transudates" or "exudates". 2 In 1972, Light et $\mathrm{al}^{3}$ compared various criteria for differentiating between transudative and exudative pleural effusion and found none of them to be specific. They advocated the use of a combination of following criteria to differentiate between transudative and exudative pleural effusion with nearly

Financial or Other, Competing Interest: None.

Submission 04-04-2017, Peer Review 28-04-2017,

Acceptance 04-05-2017, Published 11-05-2017.

Corresponding Author:

Dr. Kali Gandhi,

Junior Resident,

Department of Pathology,

S. S. Medical College,

Rewa-486001, Madhya Pradesh.

E-mail: kali05sept@gmail.com

DOI: $10.14260 /$ jemds $/ 2017 / 659$
$100 \%$ sensitivity and specificity: Pleural fluid protein to serum protein ratio $>0.5$, Pleural fluid LDH $>200 \mathrm{IU} / \mathrm{L}$, Pleural fluid LDH to serum LDH ratio >0.6. However, several prospective studies ${ }^{4-7}$ were unable to reproduce the results obtained by Light et al. ${ }^{3}$ In most of these studies, Light's criteria had a $>95 \%$ sensitivity for exudates but specificity was $<78 \%$. Various cause may be responsible for the presence of cholesterol in the pleural effusion.8-10 Light's criteria is the gold standard to differentiate transudative pleural effusion from exudative pleural effusion, but it requires four biochemical estimations which in developing countries such as India, may not be feasible in every patient due to economic constraints. The purpose of present study is comparison of Light's criteria and pleural fluid cholesterol to distinguish exudative and transudative pleural fluid.

\section{MATERIALS AND METHODS}

This prospective study was conducted in Department of Pathology, Shyam Shah Medical College and Sanjay Gandhi Memorial Hospital, Rewa (M. P.), a tertiary care hospital, from duration April 2015 to March 2016. The study comprised of 
60 patients who were admitted to SGMH with signs or symptoms of pleural effusion by adhering strictly to certain inclusion and exclusion criteria.

\section{Inclusion Criteria}

(1) Age of patient $>15$ years, (2) Clinically and radiologically demonstrable moderate to large pleural effusion, (3) Willingness of patient to participate in the study, (4) Patients of pleural effusion who have not received any therapy for his/her present disease, (5) Indoor patients.

\section{Exclusion Criteria}

(1) Age of patient $<15$ years, (2) Patients with contradictions to perform thoracocentesis like bleeding diathesis, local infection, thrombocytopenia, renal insufficiency, etc. (3) Patient's refusal, (4) Outdoor patients, (5) Patients with history of pleural effusion due to trauma.

All the patients underwent a detailed history of fever, productive or dry cough, night sweats, haemoptysis, chest pain, weight loss, lower extremity oedema, orthopnoea, paroxysmal nocturnal dyspnoea, decreased urine output, and other relevant symptoms. Clinical assessment including general survey and systemic examination were done. Blood investigations (complete haemogram, total protein, cholesterol and LDH), urine examination, chest radiograph (Postero-anterior view), electrocardiography, echocardiography, renal function test, liver function test, sputum examination for acid-fast bacilli, ultrasonography, computed tomography chest (in selected patients) were done in all the patients. Pleural fluid analysis was done for total protein, cholesterol and LDH in all the patients. Pleural fluid and serum collected at same time. Present study material comprised of patients with following clinical diagnosis. (1) Tuberculosis (TB), (2) Pneumonia, (3) Malignancy, (4) Empyema, (5) Pericardial disease, (6) Pulmonary Embolism, (7) Congestive Heart Failure (CHF) and (8) Hepatic Cirrhosis.

The protein concentrations $(\mathrm{g} / \mathrm{dL})$ were measured by using biuret method, the cholesterol was measured by using enzymatic method CHOD-PAP and the LDH was estimated by Modified IFCC Method, with the help of colorimetric estimation. For laboratory classification of pleural fluids, protein and LDH are interpreted according to the criteria of Light et al and a cut-off point of $45 \mathrm{mg} / \mathrm{dL}$ was adopted for cholesterol.11

\section{RESULTS}

This study comprised of 60 patients. All of them were inpatients both male and female with signs or symptoms of pleural effusion admitted to wards of S.G.M.H., Rewa. Patients were divided into 2 groups: patients with clinically suspected exudative effusion and patients with clinically suspected transudative effusion. A total of 60 patients were taken for study which included 52 patients with exudative effusion and 8 patients with transudative effusion.

Table 1 and Figure 1 shows the distribution of study population by type of effusion, in this exudative effusion was seen in a majority of study population i.e. $86.7 \%(n=52)$ and transudative effusion was seen in $13.3 \%(n=8)$ of study population.
Table 2 and Figure 2 shows the distribution of study population by effusion type and gender. It was observed that both exudative and transudative effusions were more prominent in male patients i.e. $75 \%(n=39)$ were male and $25 \%(n=13)$ were female out of 52 exudative effusion. Similarly, $75 \%(n=6)$ were male and $25 \%(n=2)$ were female out of 8 transudative effusions.

Table 3 and Figure 3 shows the distribution of study population by effusion type and age group. In patients with exudative effusion, the majority ( $\mathrm{n}=24$ and $46.2 \%$ ) of study population were in $>65$ years age group, followed by the 41 65 years $(n=18$ and $34.6 \%)$ and $15-40$ years $(n=10$ and $19.2 \%$ ) age groups. Similarly, in patients with transudative effusion, the majority i.e. $62.5 \%(n=5)$ of study population were in $>65$ years age group, followed by the 41-65 years $(25 \%$ and $n=2)$ and $15-45$ years $(12.5 \%$ and $n=1)$ age groups.

Table 4 and Figure 4 shows the distribution of study population by effusion type and clinical diagnosis. As can be seen from data, among the patients with exudative effusion, tuberculosis was the most common cause, diagnosed in 23 patients (44.2\%) followed by pneumonia ( 12 and 23\%), malignancy (7 and 13.3\%), empyema (5 and 9.6\%), pericardial disease ( 3 and $5.7 \%$ ) and pulmonary embolism (2 and $3.8 \%$ ). However, among the patients with transudative effusion, congestive heart failure (6 and 75\%) was the most prevalent condition, followed by hepatic cirrhosis (2 and $25 \%$ ).

Table 5 and Figure 5 shows sensitivity, specificity, positive predictive value (PPV) and negative predictive value (NPV) for differentiation of exudate and transudate while using pleural fluid cholesterol cut-off point $>45 \mathrm{mg} / \mathrm{dL}$. As from data it can be seen that sensitivity, specificity, positive predictive value (PPV) and negative predictive value (NPV) were $100 \%, 100 \%, 100 \%$ and $100 \%$ respectively, when using pleural fluid cholesterol cut off point $>45 \mathrm{mg} / \mathrm{dL}$ to differentiate exudate and transudate.

\begin{tabular}{|c|c|c|}
\hline Type of Effusion & Frequency (n) & Percentage (\%) \\
\hline Exudate & 52 & $86.7 \%$ \\
\hline Transudate & 8 & $13.3 \%$ \\
\hline Total & $\mathbf{6 0}$ & $\mathbf{1 0 0 \%}$ \\
\hline \multicolumn{3}{|c|}{ Table 1. Distribution of Study } \\
Population by type of Effusion \\
\hline
\end{tabular}

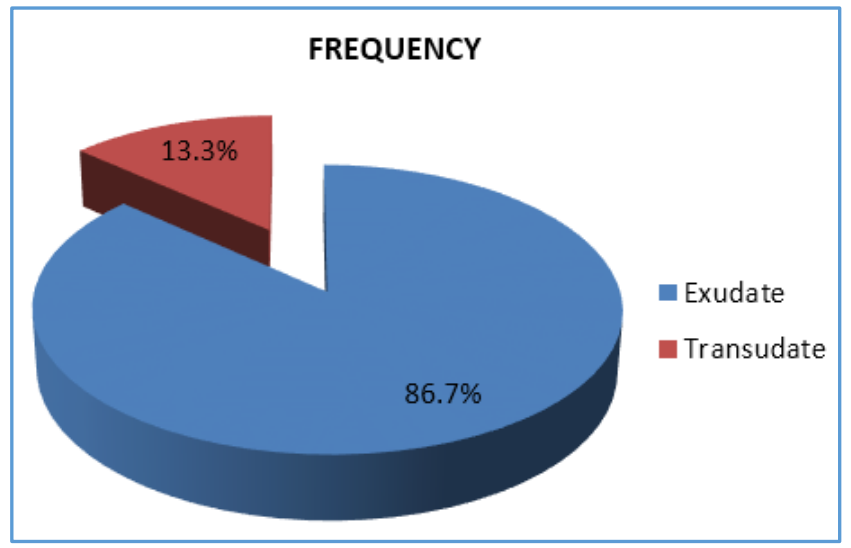

Figure 1. Distribution of Study Population by Type of Effusion 


\begin{tabular}{|c|c|c|c|c|c|c|}
\hline & \multicolumn{2}{|c|}{ Male } & \multicolumn{2}{c|}{ Female } & \multicolumn{2}{c|}{ Total } \\
\hline Effusion Type & $\mathbf{n}$ & $\mathbf{0}$ & $\mathbf{n}$ & $\mathbf{\%}$ & $\mathbf{n}$ & $\mathbf{\%}$ \\
\hline Exudate & 39 & 75 & 13 & 25 & 52 & 86.7 \\
\hline Transudate & 6 & 75 & 2 & 25 & 08 & 13.3 \\
\hline Total & $\mathbf{4 5}$ & $\mathbf{7 5}$ & $\mathbf{1 5}$ & $\mathbf{2 5}$ & $\mathbf{6 0}$ & $\mathbf{1 0 0}$ \\
\hline
\end{tabular}

Table 2. Distribution of Study Population by Effusion Type and Gender

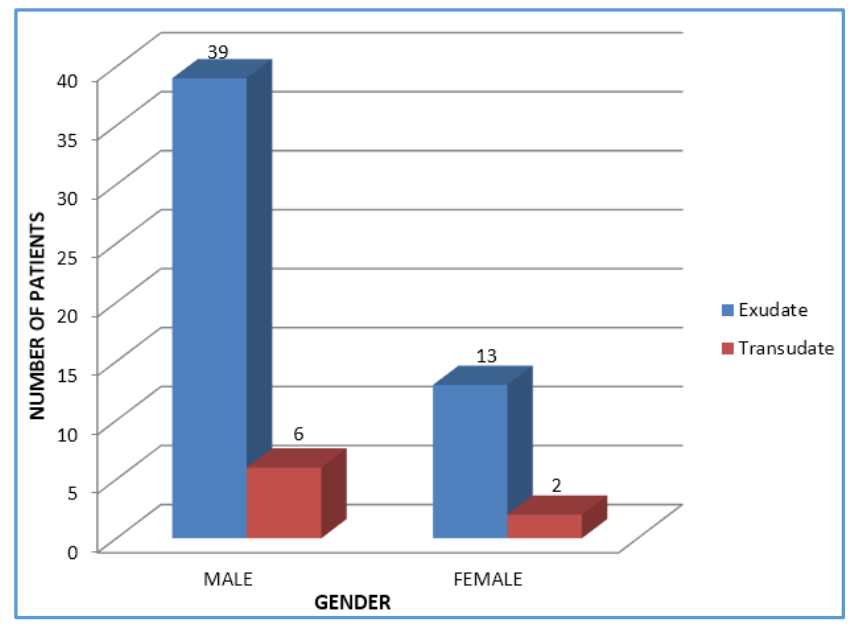

Figure 2. Distribution of Study Population by Effusion Type and Gender

\begin{tabular}{|c|c|c|c|c|c|c|c|c|}
\hline & \multicolumn{2}{|c|}{$\mathbf{1 5 - 4 0}$ yrs. } & \multicolumn{2}{|c|}{$\mathbf{4 1 - 6 5}$ yrs. } & \multicolumn{2}{c|}{$>\mathbf{6 5}$ yrs. } & \multicolumn{2}{c|}{ Total } \\
\hline Effusion type & $\mathbf{n}$ & $\mathbf{\%}$ & $\mathbf{n}$ & $\mathbf{\%}$ & $\mathbf{n}$ & $\mathbf{\%}$ & $\mathbf{n}$ & $\mathbf{\%}$ \\
\hline Exudate & 10 & $19.2 \%$ & 18 & $34.6 \%$ & 24 & $46.2 \%$ & 52 & $86.7 \%$ \\
\hline Transudate & 1 & $12.5 \%$ & 2 & $25 \%$ & 5 & $62.5 \%$ & 8 & $13.3 \%$ \\
\hline Total & $\mathbf{1 1}$ & $\mathbf{1 8 . 3 \%}$ & $\mathbf{2 0}$ & $\mathbf{3 3 . 3} \%$ & $\mathbf{2 9}$ & $\mathbf{4 8 . 4 \%}$ & $\mathbf{6 0}$ & $\mathbf{1 0 0 \%}$ \\
\hline \multicolumn{6}{|c|}{$\begin{array}{r}\text { Table 3. Distribution of Study Population } \\
\text { by Effusion Type and Age Group }\end{array}$} \\
\hline
\end{tabular}

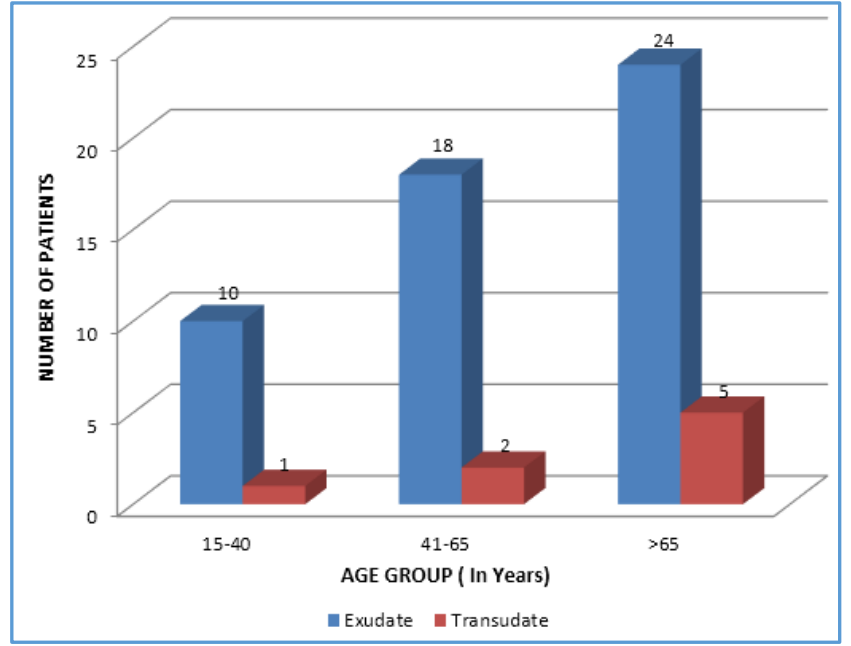

Figure 3. Distribution of Study Population by Effusion Type and Age Group

\begin{tabular}{|c|c|c|c|c|c|c|c|c|c|}
\hline & T.B. & Pneumonia & Malignancy & Empyema & $\begin{array}{l}\text { Pericardial } \\
\text { DS. }\end{array}$ & $\begin{array}{c}\text { Pulmonary } \\
\text { Embolism }\end{array}$ & CHF & $\begin{array}{c}\text { Hepatic } \\
\text { Cirrhosis }\end{array}$ & Total \\
\hline $\begin{array}{c}\text { Effusion } \\
\text { Type }\end{array}$ & $\begin{array}{c}\mathbf{n} \\
(\%)\end{array}$ & $\begin{array}{c}\mathbf{n} \\
(\%)\end{array}$ & $\begin{array}{c}n \\
(\%)\end{array}$ & $\begin{array}{c}\text { n } \\
(\%)\end{array}$ & $\begin{array}{c}n \\
(\%)\end{array}$ & $\begin{array}{c}n \\
(\%)\end{array}$ & $\begin{array}{c}n \\
(\%)\end{array}$ & $\begin{array}{c}n \\
(\%)\end{array}$ & $\begin{array}{c}\text { n } \\
(\%)\end{array}$ \\
\hline Exudate & $\begin{array}{c}23 \\
44.2 \% \\
\end{array}$ & $\begin{array}{c}12 \\
23 \%\end{array}$ & $\begin{array}{c}7 \\
13.5 \% \\
\end{array}$ & $\begin{array}{c}5 \\
9.6 \%\end{array}$ & $\begin{array}{c}3 \\
5.7 \%\end{array}$ & $\begin{array}{c}2 \\
3.8 \%\end{array}$ & $\begin{array}{c}0 \\
0 \%\end{array}$ & $\begin{array}{c}0 \\
0 \%\end{array}$ & $\begin{array}{c}52 \\
86.7 \%\end{array}$ \\
\hline Transudate & $\begin{array}{c}0 \\
0 \%\end{array}$ & $\begin{array}{c}0 \\
0 \%\end{array}$ & $\begin{array}{c}0 \\
0 \%\end{array}$ & $\begin{array}{c}0 \\
0 \%\end{array}$ & $\begin{array}{c}0 \\
0 \%\end{array}$ & $\begin{array}{c}0 \\
0 \%\end{array}$ & $\begin{array}{c}6 \\
75 \%\end{array}$ & $\begin{array}{c}2 \\
25 \%\end{array}$ & $\begin{array}{c}8 \\
13.3 \%\end{array}$ \\
\hline Total & $2338.3 \%$ & $\begin{array}{c}12 \\
20 \%\end{array}$ & $\begin{array}{c}7 \\
11.8 \% \\
\end{array}$ & $\begin{array}{c}5 \\
8.3 \%\end{array}$ & $\begin{array}{c}3 \\
5 \%\end{array}$ & $\begin{array}{c}2 \\
3.3 \%\end{array}$ & $\begin{array}{c}6 \\
10 \%\end{array}$ & $\begin{array}{c}2 \\
3.3 \% \\
\end{array}$ & $\begin{array}{c}60 \\
100 \% \\
\end{array}$ \\
\hline
\end{tabular}

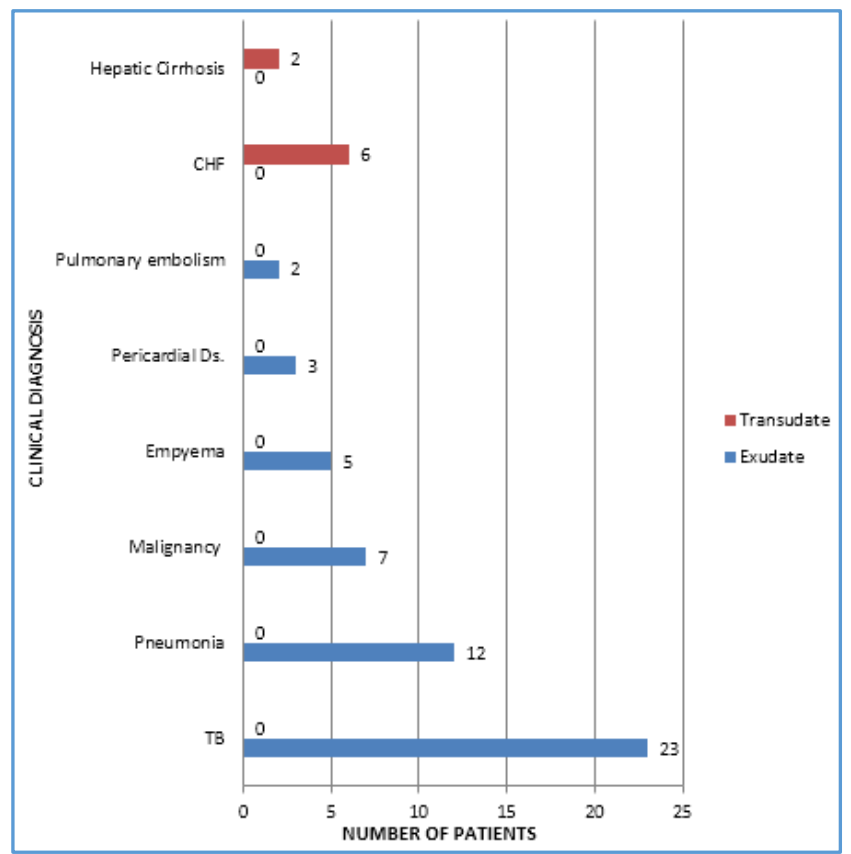

\begin{tabular}{|c|c|}
\hline Parameters & $\begin{array}{c}\text { Pleural fluid Cholesterol } \\
\text { Cut-off point } \mathbf{7 4 5} \mathbf{~} \mathbf{~ g / d L}\end{array}$ \\
\hline Sensitivity & $100 \%$ \\
\hline Specificity & $100 \%$ \\
\hline PPV & $100 \%$ \\
\hline NPV & $100 \%$ \\
\hline Table 5. Sensitivity, Specificity, PPV, and $\mathbf{N P V}$ for \\
Differentiation of Exudate and Transudate by using \\
Pleural Fluid Cholesterol Cut-off point $\mathbf{7 4 5}$ mg/dL.
\end{tabular}

Test of significance Chi-square test. $\mathrm{p}$ value $<0.0001$.

Figure 4. Distribution of Study Population by Effusion Type and Clinical Diagnosis 


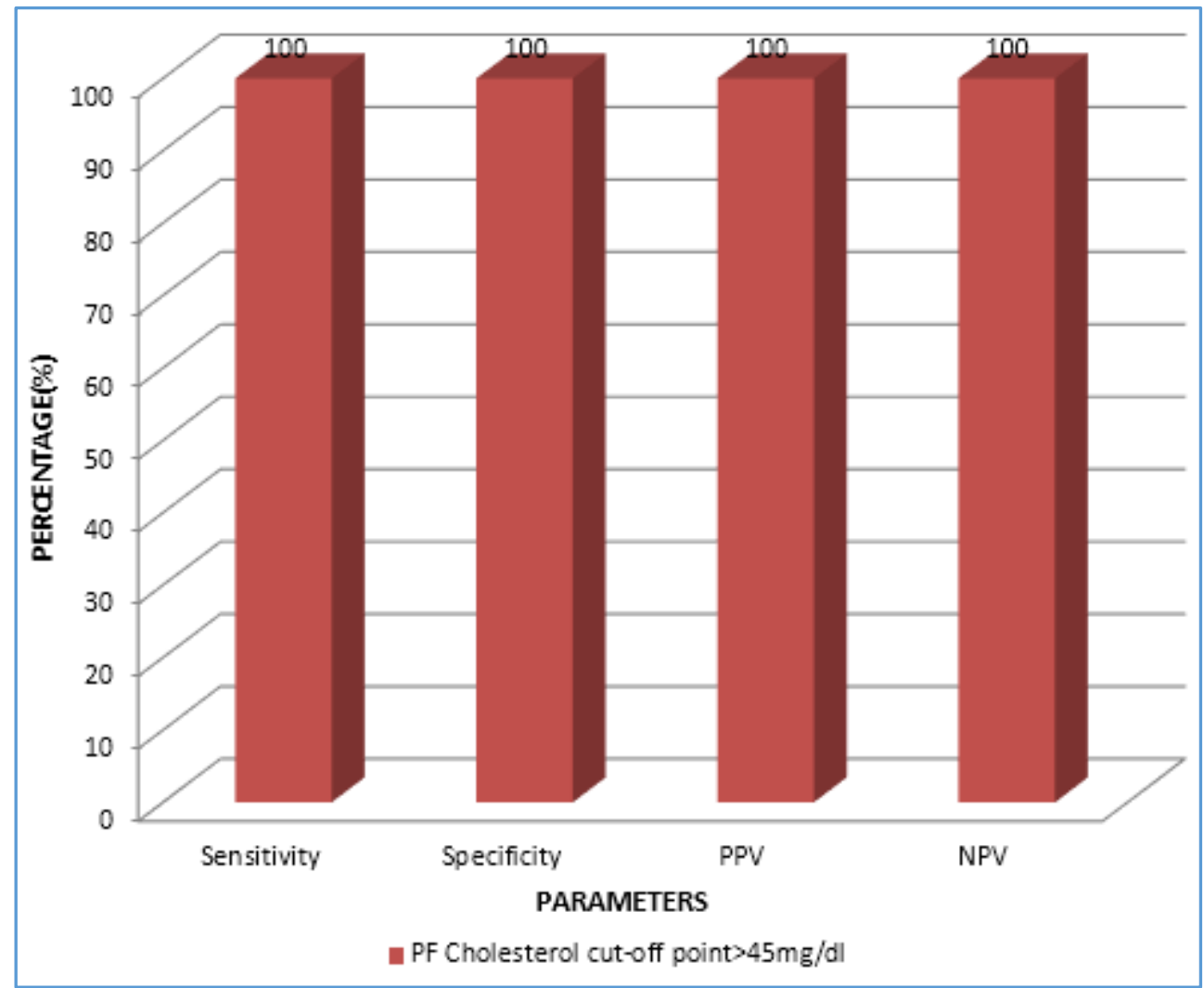

Figure 5. Sensitivity, Specificity, PPV, and NPV for Differentiation of Exudate and Transudate by using Pleural Fluid Cholesterol Cut-off Point $>45 \mathrm{mg} / \mathrm{dL}$

\begin{tabular}{|c|c|c|c|c|c|}
\hline & & $\begin{array}{c}\text { Marina } \\
\text { Costa MD et al12 }\end{array}$ & $\begin{array}{c}\text { Rohit Rungta } \\
\text { et al }{ }^{13}\end{array}$ & $\begin{array}{c}\text { Anand K. } \\
\text { Patel et al14 }\end{array}$ & $\begin{array}{c}\text { Present } \\
\text { Study }\end{array}$ \\
\hline \multirow{4}{*}{$\begin{array}{l}\text { Light's } \\
\text { Criteria }\end{array}$} & Sensitivity & $98 \%$ & $98 \%$ & $98 \%$ & $98 \%$ \\
\hline & Specificity & $82 \%$ & $82 \%$ & $100 \%$ & $87.5 \%$ \\
\hline & PPV & - & $90 \%$ & $100 \%$ & $98 \%$ \\
\hline & NPV & - & $82.9 \%$ & $92 \%$ & $87.5 \%$ \\
\hline \multirow{5}{*}{$\begin{array}{l}\text { Pleural fluid } \\
\text { Cholesterol }\end{array}$} & & $\begin{array}{l}\text { Cut-off point } \\
>45 \mathrm{mg} / \mathrm{dL}\end{array}$ & $\begin{array}{l}\text { Cut-off point } \\
>45 \mathrm{mg} / \mathrm{dL}\end{array}$ & $\begin{array}{l}\text { Cut-off point } \\
>60 \mathrm{mg} / \mathrm{dL}\end{array}$ & $\begin{array}{l}\text { Cut-off point } \\
>45 \mathrm{mg} / \mathrm{dL}\end{array}$ \\
\hline & Sensitivity & $90 \%$ & $90 \%$ & $98 \%$ & $100 \%$ \\
\hline & Specificity & $100 \%$ & $99 \%$ & $100 \%$ & $100 \%$ \\
\hline & PPV & - & $93 \%$ & $100 \%$ & $100 \%$ \\
\hline & NPV & - & $95 \%$ & $92 \%$ & $100 \%$ \\
\hline
\end{tabular}

\section{DISCUSSION}

This study was carried out on 60 patients divided into 2 groups; exudate and transudate. Exudate consists of 52 patients including patients with clinical diagnosis of tuberculosis, pneumonia, malignancy, empyema, pericardial disease, pulmonary embolism. Transudate consists of 8 patients with clinical diagnosis of congestive heart failure and hepatic cirrhosis. Out of 52 patients, 39 were male and 13 were female, with maximum number of patients falling in age group $>65$ years with mean age 57.11 years. Out of 8 patients, 6 were male and 2 were female with maximum number of patients falling in $>65$ years age group with mean age 58.62 years.
Present study demonstrates that the sensitivity, specificity, positive predictive value and negative predictive value were $98 \%, 87.5 \%, 98 \%$, and $87.5 \%$ respectively when using Light's Criteria to differentiate exudate and transudate while the sensitivity, specificity, positive predictive value and negative predictive value were $100 \%, 100 \%, 100 \%$, and $100 \%$ respectively when using pleural fluid cholesterol cutoff point $>45 \mathrm{mg} / \mathrm{dL}$ to differentiate exudate and transudate. Present study shows that using pleural fluid cholesterol to differentiate exudate and transudate was more sensitive and specific than using Light's criteria because in our study 1 exudate out of 52 exudates was misclassified as transudate (Sensitivity 98\%) and 1 out of 8 transudates was erroneously labelled as exudate (Specificity $87.5 \%$ ) when using Light's criteria to differentiate exudate and transudate. 
When using the pleural fluid cholesterol cut-off point $>45$ $\mathrm{mg} / \mathrm{dL}$, all the 52 exudates were correctly classified (sensitivity 100\%) and all the 8 transudates were correctly labelled (specificity 100\%).

Table 6 shows comparison of sensitivity, specificity, positive predictive value and negative predictive value when using Light's criteria to differentiate exudate and transudate and when using pleural fluid cholesterol to differentiate exudate and transudate among various studies.

\section{CONCLUSION}

The present study has been an attempt to determine the role of pleural fluid cholesterol and to suggest that the pleural fluid cholesterol is a better criterion than Light's criteria to differentiate exudative and transudative effusion. The sensitivity, specificity, positive predictive value and negative predictive value when using pleural fluid cholesterol to differentiate exudate and transudate is higher than the sensitivity, specificity, positive predictive value and negative predictive value when using Light's criteria to differentiate exudate and transudate. Thus, it is suggested that the measurement of pleural fluid cholesterol to differentiate exudate and transudate is better than the Light's criteria, with the advantage of no simultaneous collection of blood sample, especially in country like India where financial and technical constraints are immense.

\section{ACKNOWLEDGEMENTS}

I take this opportunity to express my sincere thanks to my seniors, Dr. Santosh Gond, Dr. Geeta and Dr. Jyoti Gupta my colleagues, Dr. Rani Sahu, Dr. Priyanka Mishra and juniors Dr. Gautam Chandrakoshi, Dr. Swarna Das, and Dr. Ajay Gupta who have helped me throughout in every possible way. I also wish to thank the technical staff of the department specially Mr. H.S. Dangi, Mr. Shyam, Mr. Jaiprakash and Mr. Shashikant for extending all possible help in my research work.

\section{REFERENCES}

[1] Suay GV, Moragón ME, Viedma CE, et al. Pleural cholesterol in differentiating transudates and exudates: a prospective study of 232 cases. Respiration 1995;62(2):57-63.
[2] Peterman TA, Speicher CE. Evaluating pleural effusion: a two-stage laboratory approach. JAMA 1984;252(8): 1051-3.

[3] Light RW, MacGregor MI, Luchsinger PC, et al. Pleural effusions: the diagnostic separation of transudates and exudates. Ann Intern Med 1972;77(4):507-13.

[4] Hamm H, Brohan U, Bohmer R, et al. Cholesterol in pleural effusions. A diagnostic aid. Chest 1987;92(2):296-302.

[5] Valdes L, Pose A, Suarez J, et al. Cholesterol: a useful parameter for distinguishing between pleural exudates and transudates. Chest 1991;99(5):1097102.

[6] Roth BJ, O'Meara TF, Cragun WH. The serum-effusion albumin gradient in the evaluation of pleural effusions. Chest 1990;98(3):546-9.

[7] Meisel S, Shamiss A, Thaler M, et al. Pleural fluid to serum bilirubin concentration ratio for the separation of transudates from exudates. Chest 1990;98(1): 141-4.

[8] Stein HM. Cholesterol thorax in tuberculosis (cholesterol pleurisy). Arch Intern Med 1932;49(3):421-8.

[9] Ferguson GC. Cholesterol pleural effusion in rheumatoid lung disease. Thorax 1966;21(6):577-82.

[10] Coe JE, Aikawa JK. Cholesterol pleural effusion. Report of 2 cases studied with isotopic techniques and review of the world literature. Arch Intern Med 1961;108(5):763-74.

[11] Quiroga T, Costa M, Sapunar FJ, et al. Uulidad de la concentration de colesterol en derramespleuralespara diferenciar entre transudados y exudados. Enferm Respir Cir Torac 1989;5(3):128-30.

[12] Costa M, Quiroga T, Cruz E. Measurement of pleural fluid cholesterol and lactate dehydrogenase. Chest 1995;108(5):1260-3.

[13] Rungta R, Jha RK. Comparative analysis of pleural fluid biochemical parameters with cholesterol to differentiate transudates from exudates. The Journal of Association of Chest Physicians 2013;1(2):54-7.

[14] Patel AK, Choudhury S. Combined pleural fluid cholesterol and total protein in differentiation of exudates and transudates. Indian J Chest Dis Allied Sci 2013;55(1):21-3. 